\title{
PROFIL KETERAMPILAN PROSES SAINS DAN SIKAP ILMIAH SISWA DI SMP SATU ATAP PULAU TUNDA
}

\author{
Aditya Rahman, Indria Wahyuni, Ika Rifqiawati \\ Surel : aditya_untirta@yahoo.co.id
}

\begin{abstract}
This research aims in descripting Science Process Competence (KPS) and student scientific behavior at SMP I Atap Pulau Tunda, Tirtayasa Region, Serang Regency. This research was an introduction research /observation to determine the study method or model that can elevate KPS and student scientific attitude. The research sample was students of SMP I Atap Pulau Tunda selected by purposive sampling. Data was collected from KPS test, observation sheets of students scientific behavior during learning process, interview sheets, and learning rank by the teacher. This research result shows that the Science Process Competence and the scientific behavior of the students were still low. Some of the reasons were the learning process was still 'teacher centered', the teacher knowledge related to KPS and the scientific behavior was still not adequate, and the training experience was still not maximum. Trainings given to teacher related to learning method and model, seminars about KPS and scientific behavior, and facilitation given by of the headmaster and the government are hopefully can elevate Science Process Competence and the scientific behavior at SMP I Atap Pulau Tunda.
\end{abstract}

Key Words: Science Process Competence, scientific behavior, and Science

\section{PENDAHULUAN}

$\begin{array}{lccr}\text { Pulau } & \text { Tunda } & \text { adalah salah } \\ \text { satu pulau } & \text { yang } & \text { terdapat di } \\ \text { Kabupaten } & \text { Serang. Pulau ini } \\ \text { memiliki } & \text { potensi } & \text { alam yang } \\ \text { melimpah. Menurut } & \text { Darus et al }\end{array}$
(2014) Pulau Tunda adalah pulau kecil yang memiliki tiga ekosistem pesisir penting, yaitu ekosistem mangrove, ekosistem padang lamun, dan ekosistem terumbu karang.

Ekosistem pesisir memiliki peran penting di dalam menjaga keseimbangan lingkungan dan sumber daya di pulau kecil sebagai satu kesatuan di dalam sistem yang komplek. Saat ini ancaman kerusakan pada ekosistem di Pulau Tunda sangatlah tinggi, salah satu isu terbesar dan hangat saat ini adalah adanya penambangan pasir laut pada Pulau Tunda yang digunakan untuk reklamasi Teluk Jakarta. Penambangan pasir laut ini memang memiliki dampak positif, akan tetapi dampak negatif dari aktivitas penambangan pasir laut jauh lebih besar jika dibandingkan oleh dampak positifnya. Terutama pada ekosistem terumbu karang yang akan menyebabkan kematian pada polip dan penurunan fotosintesa, serta akan mengakibatkan kematian pada biota karang. Kematian pada biota karang juga akan berdampak pada berkurang atau hilangnya ikan di perairan akan mengalami abrasi yang cukup intensif (Suharsono, 2006). 
Adanya potensi alam yang bagus namun saat ini terancam, maka seharusnya menjadi tugas bersama para masyarakat untuk dapat melakukan upaya pelestarian lingkungan. Guru merupakan salah satu komponen masyarakat yang berperan penting untuk menanamkan kepada siswa sikap peka terhadap lingkungan yang merupakan salah satu sikap ilmiah. Siswa di pulau tersebut merupakan generasi penerus yang akan menempati kampung halaman tercinta mereka, miris ketika tempat tinggal atau pulau Tunda terkena abrasi dan akhirnya rusak karena ulah manusia yang serakah. Oleh karena itu penanaman sikap ilmiah melalui pembelajaran yang menekankan adanya kerja ilmiah atau menekankan proses sains menjadi penting di daerah tersebut.

Keterkaitan antara KPS, sikap ilmiah dengan pembelajaran sains atau IPA sangat erat. Karakteristik sains yang mempelajari fenomena-fenomena alam sekitar, tubuh manusia, hewan, dan lainnya memerlukan adanya keterampilanketerampilan sains agar materi dapat diserap dengan baik, dan menumbuhkan sikap ilmiah yang bermanfaat bagi kehidupannya sehari-hari. Hal ini sesuai dengan pendapat Rustaman (2002), bahwa keterampilan proses sains (KPS) dan sikap ilmiah merupakan bagian dari sains itu sendiri, sehingga sangat strategis untuk dikembangkan.

Berdasarkan adanya potensi alam di Pulau Tunda dan ancaman terhadap potensi tersebut, juga pendapat bahwa beberapa jenis KPS dan sikap ilmiah memungkinkan berkembang secara alami dalam kehidupan sosial siswa (Rustaman, 2002), maka peneliti terdorong melakukan penelitian untuk mengetahui profil keterampilan proses sains dan sikap ilmiah. Selanjutnya, hasil penelitian ini akan menjadi penelitian pendahuluan sebagai bahan untuk penelitian selanjutnya yang menetapkan satu model atau metode pembelajaran yang dapat mengembangkan KPS dan sikap ilmiah siswa di Pulau Tunda. Rumusan masalah untuk penelitian ini yaitu:

a. Bagaimanakah profil keterampilan proses sains (KPS) siswa SMP Satu Atap Pulau Tunda?

b. Bagaimanakah profil sikap ilmiah siswa SMP Satu Atap Pulau Tunda?

c. Apa saja kendala yang terjadi dalam mengembangkan KPS dan sikap ilmiah siswa di SMP Satu Atap Pulau Tunda?

d. Apa saja solusi atau upaya yang dapat dilakukan untuk mengembangkan KPS dan sikap ilmiah siswa di SMP Satu Atap Pulau Tunda?

\section{METODE PENELITIAN}

Penelitian ini dilaksanakan pada bulan Agustus 2016. Penelitian ini merupakan penelitian deskriptif, dengan tujuan untuk mendeskripsikan KPS dan sikap ilmiah siswa di SMP Satu Atap Pulau Tunda. Sampel penelitian ini 
yaitu siswa SMP Satu Atap Pulau

Tunda kelas VII yang diambil dengan teknik purposive sampling. Pemilihan sampel berdasarkan hasil observasi awal yang melihat potensi alam yang dimiliki Pulau Tunda sangatlah bagus untuk dijadikan sebagai sumber belajar pembelajaran IPA, sehingga keterampilan proses sains dan sikap ilmiah siswa dapat ditumbuhkembangkan.

Hasil penelitian ini merupakan modal awal atau bahan untuk penelitian selanjutnya yaitu menentukan model atau metode pembelajaran yang sesuai diterapkan di sekolah tersebut, dengan memanfaatkan potensi alam sehingga KPS dan sikap ilmiah siswa di sekolah sampel dapat meningkat.

Instrumen yang digunakan dalam penelitian ini yaitu soal KPS dan lembar observasi sikap ilmiah siswa. Selain itu, dilakukan juga wawancara dengan guru dan siswa untuk menggali informasi lebih dalam terkait pelaksanaan pembelajaran yang biasa dilakukan di kelas, dan pengetahuan guru terkait KPS dan sikap ilmiah. Wawancara tersebut dipandu dengan adanya lembar wawancara guru dan siswa. Perangkat pembelajaran dan evaluasi kelas juga dijadikan sebagai data penunjang. Data yang dikumpulkan berupa data kualitatif, selanjutnya dianalisis menggunakan pendekatan Miles dan Huberman (Emzir, 2012), dengan cara triangulasi data.

\section{HASIL PENELITIAN DAN PEMBAHASAN}

Keterampilan proses sains yang diukur yaitu mengamati, klasifikasi, memprediksi, interpretasi, dan menggunakan alat dan bahan. Aspek KPS memprediksi memiliki persentase paling rendah dibanding aspek lainnya (20\%), dan klasifikasi memiliki persentase paling tinggi (40\%). Semua aspek KPS yang diukur selain memprediksi masuk dalam kategori rendah, sedangkan memprediksi masuk dalam kategori rendah sekali. Berikut grafik hasil pengukuran KPS siswa:

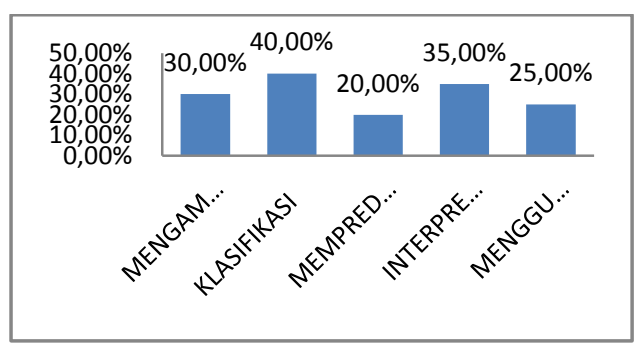

Grafik Hasil pengukuran KPS Siswa

Keterampilan klasifikasi mempunyai persentase lebih tinggi dibanding yang lainnya, karena keterampilan ini sudah dialami oleh siswa dalam kehidupan sehari-hari, dan dalam pembelajaran IPA yang telah diterima terdapat materi yang mengembangkan keterampilan ini. Keterampilan lain seperti interpretasi dan mengamati juga sering dikembangkan dalam proses pembelajaran, karena IPA memuat materi yang melatih kemampuan tersebut. Berdasarkan perkembangan usia, keterampilan ini memang seharusnya sudah dimiliki 
oleh siswa. Hasil penelitian Suja (2006) menyatakan bahwa keterampilan untuk melakukan observasi, menginterpretasikan dan mengklasifikasikan data menjadi semakin mantap pada anak kelas VI (usia 11-12 tahun). Walaupun tiga kemampuan tersebut memiliki persentase yang tinggi dibanding lainnya, namun masih masuk dalam kategori rendah. Hal ini dikarenakan proses pembelajaran yang biasa diterapkan masih bersifat teacher center, dan belum adanya menggunakan media dan sumber belajar yang menarik bagi siswa. Peningkatan keterampilanketerampilan tersebut diperlukan dengan cara pemberian metode atau model pembelajaran, media, sumber belajar, dan evaluasi yang tepat untuk setiap materi IPA yang diajarkan.

Keterampilan memprediksi dan menggunakan alat dan bahan memiliki persentase rendah. Hal ini dikarenakan proses pembelajaran yang biasa diterapkan di kelas tersebut jarang memberikan pembelajaran berupa praktikum atau pengamatan.

Kemampuan memprediksi memang harus dilatihkan secara intensif dengan cara pembelajaran praktikum. Pembelajaran dengan praktikum atau percobaan menuntut siswa untuk melakukan tahapan ilmiah salah satunya memprediksi. Keterampilan ini juga rendah dikarenakan pembelajaran belum melatih siswa untuk senang melakukan proses tanya jawab.
Selain KPS penelitian ini juga mengukur sikap ilmiah siswa di SMP Satu Atap Pulau Tunda. Sikap ilmiah yang diobservasi yaitu rasa ingin tahu, berpikir terbuka dan kerjasama, dan peka terhadap lingkungan sekitar. Selama observasi di kelas, guru menerapkan pembelajaran dengan metode ceramah. Hasil observasi sikap ilmiah dapat disajikan berikut ini:

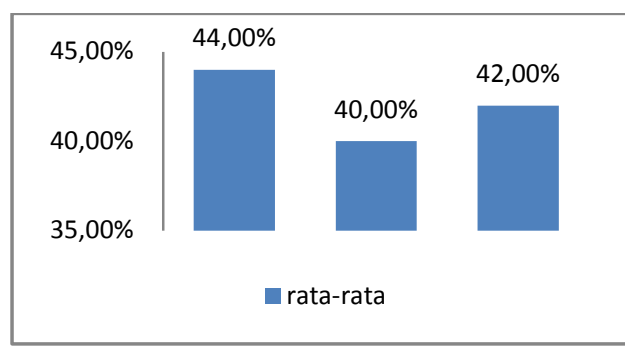

\section{Grafik Hasil Observasi Sikap Ilmiah Siswa}

Grafik di atas menyatakan bahwa sikap imilah siswa pada aspek berpikir terbuka dan kerjasama mendapatkan persentase rata-rata yang lebih rendah dibandingkan dengan sikap ilmiah lainnya (40\%), sedangkan sikap ilmiah yang paling tinggi yaitu rasa ingin tahu (44\%). Sikap berpikir terbuka dan kerjasama yang masih rendah dapat diakibatkan karena rentang usia Sekolah Menengah Pertama (SMP) yang memang masih belum matang untuk saling berkoordinasi dengan baik antar teman, masih memiliki ego yang tinggi, dan sebagainya (Wawan, 2010). Hal ini terlihat saat pembelajaran berlangsung, beberapa siswa masih belum menunjukkan 
sikap terbuka mereka terhadap saran atau pendapat dari teman lain.

Aspek sikap peka terhadap lingkungan yang diobservasi meliputi perhatian terhadap peristiwa sekitar, dan menjaga kebersihan lingkungan. Persentase rata-rata sikap ilmiah tersebut yaitu $42 \%$ yang termasuk kategori kurang. Saat observasi ditemukan bahwa siswa masih belum menyadari tentang pentingnya menjaga kebersihan lingkungan. Ditemukan siswa yang belum terbiasa memungut sampah atau membuang sampah di tempatnya ketika ditemukan sampah. Siswa juga belum memiliki sikap perhatian terhadap peristiwa sekitar yang baik, ketika ditanyakan saat wawancara tentang dampak penambangan pasir di Pulau Tunda, siswa belum tahu dampak tersebut dan merasa tidak menjadi masalah ketika pasir di tempat tinggal terus diambil. Hal ini dapat terjadi karena guru tidak menyampaikan hal tersebut dalam pembelajaran, guru kurang mampu mengkaitkan peristiwa sekitar lingkungan sekolah dengan materi IPA yang dipelajari. Hasil wawancara juga menyatakan demikian, guru belum memanfaatkan potensi lokal atau lingkungan sekitar menjadi sumber belajar. Peran guru atau orang tua untuk menanamkan sikap peka terhadap lingkungan penting bagi siswa, karena menurut Allport dalam Wawan (2010), sikap seseorang terhadap suatu objek dan situasi dipengaruhi oleh lingkungannya. Kemungkin siswa jarang dianjurkan untuk menjaga lingkungan, baik di lingkungan keluarga atau di lingkungan sekolah, sehingga sikap peka terhadap lingkungan masih belum tertanam kuat dalam diri siswa.

Sikap rasa ingin tahu siswa masuk dalam kategori kurang. Selama observasi, beberapa siswa masih belum berpartisipasi dalam pembelajaran dengan mengajukan pertanyaan. Hal ini terjadi karena guru kurang memberikan stimulus kepada siswa untuk bertanya, dan tidak adanya objek menarik yang ditampilkan. Keterampilan bertanya harus sering dilatihkan kepada siswa, adanya objek atau peristiwa yang menarik menstimulus siswa untuk bertanya (Rifqiawati, 2013).

\section{Pembahasan}

Hasil penelitian menyatakan KPS dan sikap ilmiah siswa di SMP Satu Atap Pulau Tunda masih rendah. KPS dan sikap ilmiah siswa yang belum dikembangkan membutuhkan treatment yang tepat bagi siswa, salah satunya dengan pemberian metode atau model pembelajaran yang dapat mengembangkan KPS dan sikap ilmiah. Penggunaan metode atau model pembelajaran yang tepat merupakan pengetahuan yang harus dimiliki oleh guru. Berdasarkan hasil wawancara, guru baru mendapatkan atau mengikuti pelatihan terkait pembelajaran dua kali. Pelatihan terkait pembelajaran jarang diadakan oleh sekolah, penugasan untuk pelatihan di luar pulau juga belum pernah. Selain itu, kurangnya tenaga 
pengajar di Pulau Tunda membuat satu guru bisa mengajar beberapa bidang studi, dan pendidikan terakhir rata-rata hanya sampai SMA. Peran serta dinas pendidikan setempat diperlukan di daerah ini, untuk pengadaan guru dan fasilitas lainnya. Hasil penelitian ini juga penting bagi Perguruan Tinggi atau Universitas dalam mengembangkan pelatihan bagi guru SMP, khususnya guru di daerah terpencil seperti Pulau Tunda. Diharapkan treatment yang tepat diberikan kepada guru, dapat menjadikan guru lebih profesional dalam mengembangkan KPS dan sikap ilmiah.

\section{SIMPULAN}

Hasil penelitian menyatakan bahwa KPS siswa SMP Satu Atap Pulau Tunda masih rendah. Aspek KPS yang diukur yaitu mengamati, klasifikasi, memprediksi, interpretasi, dan menggunakan alat dan bahan. Sikap ilmiah juga didapatkan hasil yang rendah. Beberapa penyebab rendahnya KPS dan sikap ilmiah siswa yaitu tidak tepatnya metode atau model pembelajaran yang diberikan oleh guru, karena kurangnya pengetahuan guru terkait KPS dan sikap ilmiah. Sekolah jarang memberikan pelatihan terkait pembelajaran bagi para guru. Selain itu, dalam penelitian ini ditemukan pula guru belum memanfaatkan potensi lokal atau lingkungan sekitar sebagai sumber belajar. Berdasarkan hasil pembahasana tersebut, maka diperlukan adanya peran serta dinas pendidikan terkait, dan institusi seperti perguruan tinggi untuk mengadakan pelatihan bagi guru SMP, khususnya guru di daerah terpencil seperti Pulau Tunda.

\section{DAFTAR RUJUKAN}

Darus. 2014. Keanekaragaman Hayati Ekosistem Pesisir DibPulau Tunda, Kabupaten Serang, Banten. Prosiding Semnas Kelautan Universitas Trunojoyo Madura. ISBN 978602-7998-89-6.

Emzir. 2012. Analisis Data Metodologi Penelitian Kualitatif. Jakarta: Rajawali Press.

Rifqiawati, I. 2013. Kajian Implementasi Scientific Approach Pada Mata Pelajaran Biologi Kaitannya Dengan Kurikulum 2013 (Makalah Tugas Mata Kuliah Studi Kasus). Tidak dipublikasikan, Universitas Pendidikan Indonesia.

Rustaman, Nuryani. 2002. Pengembangan Butir Soal Keterampilan Proses Sains. Makalah Bahan Piloting Biologi. Tidak dipublikasikan. FPMIPA UPI.

Slameto. 1995. Belajar dan Faktorfaktor yang Mempengaruhinya. Jakarta: Rineka Cipta.

Suharsono, 2006. Pertumbuhan Karang. Oseana. Pusat Penelitian Biologi Laut. LON-LIPI. 9(2): 41-48.

Suja, I.W. 2006. Profil Kompetensi Keterampilan Proses Sains Siswa 
Sekolah Dasar Di Kecamatan

Buleleng. Jurnal Pendidikan dan Pengajaran IKIP Negeri Singaraja, No. 4 TH.XXXIX Januari 2006. ISSN 0215-8250. hlm. 776.
Wawan, A. dan M. Dewi. 2010. Teori dan Pengukuran Pengetahuan, Sikap, dan Perilaku Manusia. Yogyakarta: Nuha Medika. 